\title{
Nocardia concava sp. nov., isolated from Japanese patients
}

\author{
Akiko Kageyama, ${ }^{1}$ Katsukiyo Yazawa, ${ }^{1}$ Hiroko Taniguchi, ${ }^{1}$ Hiroji Chibana, ${ }^{1}$ \\ Kazuko Nishimura, ${ }^{1}$ Reiner M. Kroppenstedt ${ }^{2}$ and Yuzuru Mikami ${ }^{1}$ \\ ${ }^{1}$ Research Center for Pathogenic Fungi and Microbial Toxicoses, Chiba University, 1-8-1 \\ Inohana, Chuo-ku, Chiba 260-8673, Japan \\ ${ }^{2}$ Deutsche Sammlung von Mikroorganismen und Zellkulturen, Braunschweig, Germany
}

Correspondence

Yuzuru Mikami

mikami@faculty.chiba-u.jp
The genus Nocardia has been well defined on the basis of chemotaxonomic, molecular genetic and numerical phenetic methods (Goodfellow et al., 1999). Members of the genus are common and widely distributed in terrestrial habitats (Gordon et al., 1974; Goodfellow, 1998; Wang et al., 2001; Albuquerque de Barros et al., 2003; Zhang et al., 2003). Many Nocardia species are associated with human and animal infections that are difficult to diagnose because they do not present specific clinical manifestations and histological data are lacking (Gordon et al., 1974, Boiron et al., 1992; Goodfellow, 1998; Yassin et al., 2000, 2003). The two bacterial strains studied in this work (IFM $0354^{\mathrm{T}}$ and IFM 0576) were isolated from Japanese patients with cutaneous nocardiosis. The strains were most similar to Nocardia otitidiscaviarum and Nocardia uniformis in their biochemical characteristics.

Strains IFM $0354^{\mathrm{T}}$ and IFM 0576 were isolated from a 76-year-old female patient in 1991 and from a 69-year-old male patient in 1995, respectively. The strains were cultured for morphological observations and chemotaxonomic and molecular analyses at $30^{\circ} \mathrm{C}$ as described previously (Kageyama et al., 2004a, b). The reference strain Nocardia seriolae JCM $3360^{\mathrm{T}}$ (Kudo et al., 1988) was grown on the same medium at $25^{\circ} \mathrm{C}$. For fatty acid and mycolic acid study, strain IFM $0354^{\mathrm{T}}$ and type strains of N. seriolae,

The GenBank/EMBL/DDBJ accession numbers for the 16S rRNA gene sequences of Nocardia concava IFM $0354^{\top}$ and IFM 0576 are AB126880 and AB126881, respectively.

An extended phylogenetic tree and tables detailing the fatty acid profiles, mycolic acid patterns and phenotypic properties of IFM $0354^{\top}$, IFM 0576 and other Nocardia species are available as supplementary material in IJSEM Online.
$N$. otitidiscaviarum and $N$. uniformis were grown on trypticase soy broth agar (DSMZ medium 535) at $28^{\circ} \mathrm{C}$ for 7 days.

Biochemical, physiological and chemotaxonomic characteristics, except for mycolic acid patterns, were examined as reported by Kageyama et al. (2004a, b), using the methods described by Gordon et al. (1974), Staneck \& Roberts (1974), Lechevalier \& Lechevalier (1980), Miyadoh (2001), Sasser (1990), Kämpfer \& Kroppenstedt (1996) and Chun \& Goodfellow (1995). Mycolic acid trimethylsilyl ethers were prepared and analysed following the methods of Klatte et al. (1994). Extraction of genomic DNA, DNA-DNA hybridization experiments and determination and analysis of 16S rRNA gene sequences were performed as reported by Kageyama et al. (2004a, b).

Phylogenetic trees were constructed using the neighbourjoining method (Saitou \& Nei, 1987). The topology of the trees was evaluated by a bootstrap analysis of the sequence data using CLUSTAL W software (Thompson et al., 1994). Sequence similarity values were determined by visual comparison and manual calculation.

The nearly complete $16 \mathrm{~S}$ rRNA gene sequences were determined for strains IFM $0354^{\mathrm{T}}$ (1472 bp) and IFM 0576 (1447 bp). Phylogenetic analysis demonstrated that the strains belonged to the family Nocardiaceae of the suborder Corynebacterineae (Stackebrandt et al., 1997) and formed a monophyletic clade associated with N. seriolae (Fig. 1; an extended tree showing a larger selection of reference sequences is available as Supplementary Fig. S1 in IJSEM Online). 16S rRNA gene sequence similarity between IFM $0354^{\mathrm{T}}$ and IFM 0576 was $99 \cdot 5 \%$; similarity between 


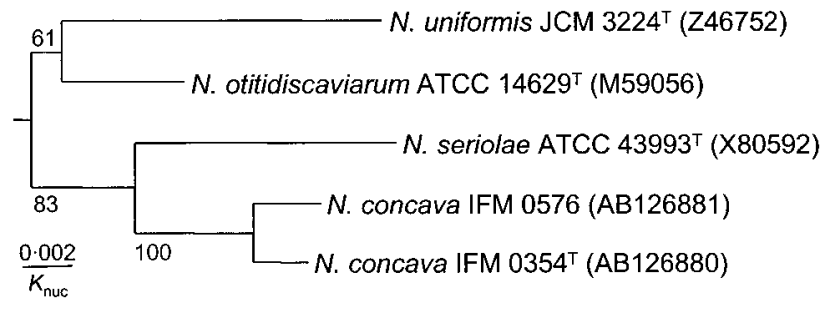

Fig. 1. Phylogenetic tree derived from 16S rRNA gene sequence analysis. The tree was created using the neighbourjoining method and $K_{\text {nuc }}$ values. Numbers on the tree indicate bootstrap values for the branch points. An extended version of this tree including a wider selection of reference strains is available as Supplementary Fig. S1 in IJSEM Online.

$N$. seriolae and the above strains was nearly $98 \cdot 1 \%$. Lower levels of sequence similarity ( $<98 \%)$ were observed with other neighbouring species, including $N$. otitidiscaviarum and N. uniformis. Genomic delineation of the isolated strains from $N$. seriolae was supported by DNA-DNA relatedness data. The two isolates shared $97 \%$ DNA-DNA relatedness, whereas relatedness values of IFM $0354^{\mathrm{T}}$ and IFM 0576 to N. seriolae were only 16 and $12 \%$, respectively. These values are well below the $70 \%$ cut-off point recommended for the delineation of genomic species (Wayne et al., 1987).

The chemotaxonomic characters of the two isolated strains were consistent with their assignment to the genus Nocardia (Goodfellow, 1998; Goodfellow et al., 1999). The strains contained galactose and arabinose as characteristic wholecell sugars in addition to meso-diaminopimelic acid as the diagnostic cell-wall diamino acid. The major menaquinone was MK- $8\left(\mathrm{H}_{4 \omega-\text {-cycl }}\right)$. The fatty acid profile of IFM $0354^{\mathrm{T}}$ included straight-chain saturated and unsaturated fatty acids plus a significant amount of tuberculostearic acid (10methyl octadecanoic acid) (see Supplementary Table S1 available in IJSEM Online). The strain also contained a homologous series of mycolic acids ranging from 52 to 62 carbon atoms, with C56 and C54 being the principal chain lengths (Supplementary Table S2). In contrast to IFM $0354^{\mathrm{T}}, N$. seriolae synthesized mycolic acids in the range from 46 to 58 carbon atoms, with the principal mycolic acid being of chain length C52 (Kudo et al., 1988), whereas $N$. otitidiscaviarum and $N$. uniformis had mainly quantitative differences in the proportions of mycolic acids present.

Strains IFM $354^{\mathrm{T}}$ and IFM 0576 were also examined for a set of biochemical and physiological characteristics in comparison with N. seriolae and Nocardia asteroides. The two strains could be readily distinguished from these species by a combination of physiological and biochemical characteristics, including decomposition of adenine, hypoxanthine, urea and xanthine (Table 1). They also differed phenotypically from other Nocardia species (see Supplementary Table S3 in IJSEM Online).
Table 1. Phenotypic properties of the isolated strains, $N$. asteroides and $N$. seriolae

Strains: 1, IFM $0354^{\mathrm{T}}$; 2, IFM 0576; 3, N. asteroides ATCC $19247^{\mathrm{T}}$; 4, N. seriolae JCM $3360^{\mathrm{T}}$. Data were taken from Kinoshita et al. (2001), Kudo et al. (1988), Yassin et al. (2000) and this study. +, Positive; -, negative; ND, no data.

\begin{tabular}{|c|c|c|c|c|}
\hline Characteristic & 1 & 2 & 3 & 4 \\
\hline \multicolumn{5}{|l|}{ Decomposition of: } \\
\hline Adenine & + & + & - & - \\
\hline Hypoxanthine & + & + & - & - \\
\hline Tyrosine & + & + & - & - \\
\hline Urea & + & + & + & - \\
\hline Xanthine & + & + & - & - \\
\hline \multicolumn{5}{|l|}{ Utilization of: } \\
\hline Arabinose & + & + & - & - \\
\hline Galactose & + & + & - & - \\
\hline Inositol & + & + & - & - \\
\hline Mannose & + & + & ND & ND \\
\hline Growth at $37^{\circ} \mathrm{C}$ & + & + & + & - \\
\hline \multicolumn{5}{|l|}{ Susceptibility tests:* } \\
\hline Imipenem $^{a}$ & - & - & $3+$ & ND \\
\hline Tobramycin $^{a}$ & $2+$ & $2+$ & $3+$ & ND \\
\hline 5-Fluorouracil ${ }^{b}$ & + & + & - & ND \\
\hline Kanamycin $^{c}$ & $3+$ & $3+$ & $1+$ & ND \\
\hline
\end{tabular}

${ }^{\star}$ Scored as follows. $a$ : $3+$, highly susceptible, growth inhibition at $2.5 \mu \mathrm{g}$ per disc; $2+$, moderately susceptible, growth inhibition at $5 \cdot 0 \mu \mathrm{g}$ per disc; - , not susceptible, no growth inhibition at $10 \cdot 0 \mu \mathrm{g}$ per disc. $b$ : + , susceptible, growth inhibition at $30.0 \mu \mathrm{g}$ per disc; - , not susceptible, no growth inhibition at $30.0 \mu \mathrm{g}$ per disc. $c: 3+$, highly susceptible, growth inhibition at $5 \cdot 0 \mu \mathrm{g}$ per disc; $1+$, slightly susceptible, growth inhibition at $30 \cdot 0 \mu \mathrm{g}$ per disc.

On the basis of the genotypic and phenotypic evidence described above, it was concluded that strains IFM $354^{\mathrm{T}}$ and IFM 0576 represented a novel species within the genus Nocardia. We therefore propose the name Nocardia concava sp. nov.

\section{Description of Nocardia concava sp. nov.}

Nocardia concava (con.ca'va. L. fem. adj. concava hollow, concave, referring to the colony morphology on agar plates).

Aerobic Gram-positive, acid-alcohol-fast, non-motile actinomycete, which forms greyish-orange to faint-orange substrate mycelium that fragments into irregular rodshaped elements. Aerial mycelium is absent to scanty. Grows at $37^{\circ} \mathrm{C}$, but not at $45^{\circ} \mathrm{C}$. Colonies are $1 \cdot 0-3.5 \mathrm{~mm}$ in size after growth for 7 days at $30^{\circ} \mathrm{C}$ on MH II agar medium with $0 \cdot 2 \%$ glucose. Erythritol, maltose, mannose, rhamnose and sorbitol are not utilized. Arabinose, galactose, glucose, inositol and citrate are utilized. Casein and tyrosine are not decomposed. Adenine, hypoxanthine, urea and xanthine are decomposed. The DNA G $+\mathrm{C}$ content is $67-68 \mathrm{~mol} \%$. 
The type strain is IFM $0354^{\mathrm{T}}\left(=\mathrm{NBRC} 100430^{\mathrm{T}}=\mathrm{JCM}\right.$ $\left.12351^{\mathrm{T}}=\mathrm{DSM} 44804^{\mathrm{T}}\right)$. A second strain is IFM 0576. These strains are isolates from Japanese patients.

\section{References}

Albuquerque de Barros, E. V., Manfio, G. P., Ribeiro Maitan, V., Mendes Bataus, L. A., Kim, S. B., Maldonado, L. A. \& Goodfellow, M. (2003). Nocardia cerradoensis sp. nov., a novel isolate from Cerrado soil in Brazil. Int J Syst Evol Microbiol 53, 29-33.

Boiron, P., Provost, F., Chevrier, G. \& Dupont, B. (1992). Review of nocardial infections in France 1987 to 1990. Eur J Clin Infect Dis 11, 709-714.

Chun, J. \& Goodfellow, M. (1995). A phylogenetic analysis of genus Nocardia with $16 \mathrm{~S}$ rRNA gene sequences. Int J Syst Bacteriol 45, 240-245.

Goodfellow, M. (1998). Nocardia and related genera. In Topley \& Wilson's Microbiology \& Microbial Infections, 9th edn, vol. 2, pp. 463489. Edited by A. Balows \& B. I. Duerden. London: Edward Arnold.

Goodfellow, M., Isik, K. \& Yates, E. (1999). Actinomycete systematics: an unfinished synthesis. Nova Acta Leopold NF80, 47-82.

Gordon, R. E., Barnett, D. A., Handerhan, J. E. \& Pang, C. H.-N. (1974). Nocardia coeliaca, Nocardia autotrophica, and the nocardin strain. Int J Syst Bacteriol 24, 54-63.

Kageyama, A., Poonwan, N., Yazawa, K., Mikami, Y. \& Nishimura, K. (2004a). Nocardia asiatica sp. nov., isolated from patients with nocardiosis in Japan and clinical specimens from Thailand. Int J Syst Evol Microbiol 54, 125-130.

Kageyama, A., Yazawa, K., Nishimura, N. \& Mikami, Y. (2004b). Nocardia inohanensis sp. nov., Nocardia yamanashiensis sp. nov., and Nocardia niigatensis sp. nov. isolated from clinical specimens. Int J Syst Evol Microbiol 54, 563-569.

Kämpfer, P. \& Kroppenstedt, R. M. (1996). Numerical analysis of fatty acid patterns of coryneform bacteria and related taxa. Can J Microbiol 42, 989-1005.

Kinoshita, N., Homma, Y., Igarashi, M., Ikeno, S., Hori, M. \& Hamada, M. (2001). Nocardia vinacea sp. nov. Actinomycetologica 15, $1-5$.

Klatte, S., Rainey, F. A. \& Kroppenstedt, R. M. (1994). Transfer of Rhodococcus aichiensis Tsukamurella 1982 and Nocardia amarae Lechevalier and Lechevalier 1974 to the genus Gordona as Gordona aichiensis comb nov. and Gordona amarae comb nov. Int J Syst Bacteriol 44, 769-773.

Kudo, T., Hatai, K. \& Seino, A. (1988). Nocardia seriolae sp. nov. causing nocardiosis of cultured fish. Int J Syst Bacteriol 38, 173-178.

Lechevalier, M. P. \& Lechevalier, H. A. (1980). The chemotaxonomy of actinomycetes. In Actinomycete Taxonomy, pp. 227-291. Edited by A. Dietz \& D. W. Thayer. Fairfax, VA: Society for Industrial Microbiology.

Miyadoh, M. (2001). Identification procedure at the genus level. In Identification Manual of Actinomycetes, pp. 9-19. Edited by S. Miyadoh, M. Hamada, K. Hotta, T. Kudo, A. Seino, K. Suzuki \& A. Yokota. Tokyo: Business Center for Academic Societies Japan.

Saitou, N. \& Nei, M. (1987). The neighbor-joining method: a new method for reconstructing phylogenetic trees. Mol Biol Evol 4, 406-425.

Sasser, M. (1990). Identification of bacteria by gas chromatography of cellular fatty acids. USFCC Newsl 20, 1-6.

Stackebrandt, E., Rainey, F. A. \& Ward-Rainey, N. L. (1997). Proposal for a new hierarchic classification system, Actinobacteria class nov. Int J Syst Bacteriol 47, 479-491.

Staneck, J. L. \& Roberts, G. D. (1974). Simplified approach to identification of aerobic actinomycetes by thin-layer chromatography. Appl Microbiol 28, 226-231.

Thompson, J. D., Higgins, D. G. \& Gibson, T. J. (1994). CLUSTAL W: improving the sensitivity of progressive multiple sequence alignment through sequence weighting, position-specific gap penalties and weight matrix choice. Nucleic Acids Res 22, 4673-4680.

Wang, L., Zhang, Y., Lu, Z., Shi, Y., Liu, Z., Maldonado, L. \& Goodfellow, M. (2001). Nocardia beijingensis sp. nov., a novel isolate from soil. Int J Syst Evol Microbiol 51, 1783-1788.

Wayne, L. G., Brenner, D. J., Colwell, R. R. \& 9 other authors (1987). Report of the ad hoc committee on reconciliation of approaches to bacterial systematics. Int J Syst Bacteriol 37, 463-464.

Yassin, A. F., Rainey, F. A., Mendrock, U., Brzezinka, H. \& Schaal, K. P. (2000). Nocardia abscessus sp. nov. Int J Syst Evol Microbiol 50, 1487-1493.

Yassin, A. F., Sträubler, B., Schumann, P. \& Shaal, K. P. (2003). Nocardia puris sp. nov. Int J Syst Evol Microbiol 53, 1595-1599.

Zhang, J., Liu, Z. \& Goodfellow, M. (2003). Nocardia caishijiensis sp. nov., a soil actinomycete. Int J Syst Evol Microbiol 53, 999-1004. 